\title{
The limits of testing particle-mediated oxidative stress in vitro in predicting diverse pathologies; relevance for testing of nanoparticles
}

\author{
Ken Donaldson*1, Paul JA Borm², Vincent Castranova ${ }^{3}$ and Mary Gulumian ${ }^{4}$
}

\begin{abstract}
Address: ${ }^{1} \mathrm{MRC} /$ University of Edinburgh Centre for Inflammation Research, ELEGI Colt Laboratory, Queen's Medical Research Institute, 47 Little France Crescent, Edinburgh, EH16 4TJ, UK, 2Zuyd University, Nieuw Eyckholt 300, Heerlen, Limburg, 6400 AN, The Netherlands, ${ }^{3}$ National Institute for Occupational Safety and Health, 1095 Willowdale Road, Morgantown, West Virginia, USA and ${ }^{4}$ National Institute for Occupational Health, P O Box 4788, Johannesburg 2000, University of the Witwatersrand, Witwatersrand, South Africa
\end{abstract}

Email: Ken Donaldson* - ken.donaldson@ed.ac.uk; Paul JA Borm - p.borm@hszuyd.nl; Vincent Castranova - vic1@cdc.gov; Mary Gulumian - Mary.Gulumian@nioh.nhls.ac.za

* Corresponding author

Published: 27 April 2009

Particle and Fibre Toxicology 2009, 6:13 doi:10.1186/1743-8977-6-13
Received: 26 November 2008

Accepted: 27 April 2009

This article is available from: http://www.particleandfibretoxicology.com/content/6/1//3

(c) 2009 Donaldson et al; licensee BioMed Central Ltd.

This is an Open Access article distributed under the terms of the Creative Commons Attribution License (http://creativecommons.org/licenses/by/2.0), which permits unrestricted use, distribution, and reproduction in any medium, provided the original work is properly cited.

\begin{abstract}
In vitro studies with particles are a major staple of particle toxicology, generally used to investigate mechanisms and better understand the molecular events underlying cellular effects. However, there is ethical and financial pressure in nanotoxicology, the new sub-specialty of particle toxicology, to avoid using animals. Therefore an increasing amount of studies are being published using in vitro approaches and such studies require careful interpretation. We point out here that 3 different conventional pathogenic particle types, $\mathrm{PM}_{10}$, asbestos and quartz, which cause diverse pathological effects, have been reported to cause very similar oxidative stress effects in cells in culture. We discuss the likely explanation and implications of this apparent paradox, and its relevance for testing in nanotoxicology.
\end{abstract}

\section{The nanoparticle testing problem}

It is well-recognised that nanoparticles pose a problem for toxicological testing. Nanoparticles represent a broad class of materials that have come under ever greater scrutiny, yet there is little generic evidence on which endpoints to choose to predict potential pathogenicity. Nanoparticles may cause effects like 'conventional particles' but to a greater degree because of their greater surface area per unit mass. In addition, they may translocate to the blood or brain and cause other effects. Nanoparticles come in an array of compositions, sizes, shapes and with modified surfaces, all of which could alter toxicity. The sheer number of variants that need testing has stimulated a move towards the idea that in vitro testing might provide an answer to the otherwise large scale animal testing, that is both expensive and time consuming. Indeed, Nel et al. [1] have proposed that generation of reactive species and induction of oxidant stress may form the basis for development of in vitro screening methodology. In contrast, Oberdorster et al. [2] summarized the views of a panel of nano scientists which placed in vivo studies as primary to the evaluation of potential health hazard of nanoparticles. We point out here the potential dangers of exclusive use of an in vitro screening approach in view of experience with other particles, suggesting that particles can cause a rather narrow range of effects on cells in culture which does not reflect the range of different pathogenic effects they cause in vivo. This is likely in large part due to the 
issue of translocation and toxicokinetics, which is one of the most under-researched areas in nanoparticle toxicology, as well as for conventional particle toxicology.

\section{Diverse effects of different particles in causing disease}

It is an apparent paradox that exposure to different kinds of particles causes a range of different adverse effects whilst, in vitro at the cellular/molecular level, they have been found to influence similar pathways and mechanisms, mostly based around oxidative stress. The particles under consideration here are asbestos, quartz and $\mathrm{PM}_{10}$ and the different diseases they are associated with are indicated in Table 1. As is evident from Table 1, the different particle types cause different types of pathological effects despite their deposition in the same target tissue, namely the airspaces of the lung. Protracted exposure to the different particle types results in quite different types of pathological response.

\section{Similar effects of particles in vitro}

Numerous in vitro studies indicate that asbestos, quartz and $\mathrm{PM}_{10}$ have similar activities in cells in vitro - via oxidative stress, activation of NF- $\mathrm{B}$, pro-inflammatory effects and oxidative adduct formation (Table 2) [3-24]. We submit that this paradox, i.e. the mismatch between the similarities in effect seen in vitro and the differences in disease seen in vivo, poses a threat to the utility of in vitro nanotoxicology.

In addition, there are other examples where in vitro testing has been shown to misclassify health hazard. The first would be glass fibres. Glass fibres have been reported to be positive in cell testing studies: generating reactive oxygen species, causing oxidant stress, causing DNA damage, inducing chromosomal aberrations, causing multinuclear formation, and inducing cell transformation [25]. However, due to lack of biopersistence, glass fibres have been reported to exhibit a low pathogenic potential in animal models. A similar false positive in vitro result has been reported for kaolin, being as cytotoxic as quartz in cell studies but exhibiting substantially lower fibrogenicity in exposed workers [26]. Lastly, a false negative has been reported for purified single-walled carbon nanotubes, which do not generate oxidant production or induce extensive toxicity in cultured macrophages but result in progressive interstitial fibrosis in mice exposed by pharyngeal aspiration or inhalation $[27,28]$.

\section{Fibrosis}

Exposure to all 3 particle types discussed in table 1 causes fibrosis, associated with accumulation of connective tissue cells and their products. At the cellular level, exposure to these particles is associated with oxidant production, activation of macrophages, sustained release of inflammatory mediators and growth factors, and activation of extracellular matrix production by fibroblasts. There are, however, differences in the nature and site of the fibrosis with the different particles. Asbestos causes predominantly an interstitial fibrosis in the lung parenchyma and small airways fibrosis [29]. Pleural plaques are also fibrotic lesions composed almost entirely of collagen, which occur on the parietal pleura in asbestos-exposed individuals [29]. In contrast, quartz is best-known for its association with nodular fibrosis (silicosis) of the lung parenchyma. Silica may also cause small airways fibrosis and pleural fibrosis but it is not characterized by pleural plaques. The association of $\mathrm{PM}_{10}$ with COPD in chronic exposure studies and a pathology study by Churg et al. [30] strongly implicate $\mathrm{PM}_{10}$ in causing airway fibrosis. It is not immediately clear why PM should cause airway fibrosis, yet not interstitial or nodular fibrosis, except perhaps that the severity of the inflammation caused by PM10 in a low exposure environmental situation is much less than that caused by quartz and asbestos in a high exposure occupational setting. Cigarette smoke does not cause nodular parenchyma fibrosis but does cause interstitial fibrosis [31]. Intrinsic differences in the shape, surface activity and composition of asbestos, quartz and $\mathrm{PM}_{10}$ might also explain differences in pathogenicity. Differences in site of deposition do not offer an explanation, as respiratory zone deposition can occur with quartz or asbestos and for the fine particles in PM and cigarette smoke [32]. The antioxidant defences in the parenchyma

Table I: Particle-specific adverse health effects of the 3 particle types under consideration.

\begin{tabular}{|c|c|c|}
\hline & Adverse effects & \\
\hline Particle & Pulmonary & Extra-pulmonary \\
\hline Asbestos & $\begin{array}{l}\text { Interstitial fibrosis, bronchogenic carcinoma, pleural mesothelioma, pleural } \\
\text { fibrosis, pleural plaques }\end{array}$ & Peritoneal mesothelioma, Autoimmune disease \\
\hline Quartz & $\begin{array}{l}\text { Nodular fibrosis, small airways disease, bronchogenic carcinoma, pleural } \\
\text { fibrosis }\end{array}$ & Autoimmune disease \\
\hline $\mathrm{PM}_{10}$ & $\begin{array}{l}\text { Increased lung cancer risk Exacerbations of COPD, Development of COPD } \\
\text { Exacerbations of asthma }\end{array}$ & Deaths and hospitalisations for cardiovascular \\
\hline
\end{tabular}


Table 2: Studies showing significant effects of the different particle types on inflammatory, genotoxic and oxidative stress endpoints in vitro

\begin{tabular}{|c|c|c|c|c|c|c|c|c|}
\hline \multirow[b]{2}{*}{ Particle } & \multicolumn{8}{|c|}{ Endpoint } \\
\hline & $\begin{array}{l}\text { Oxidative } \\
\text { stress }\end{array}$ & $\begin{array}{c}\mathbf{N F}-\kappa \mathbf{B} \\
\text { activation }\end{array}$ & $\begin{array}{c}\text { AP-I } \\
\text { Activation }\end{array}$ & $\begin{array}{l}\text { Chemokine } \\
\text { production } \\
\text { epithelial cells }\end{array}$ & $\begin{array}{c}\text { TNF } \alpha \\
\text { production } \\
\text { macs }\end{array}$ & $\begin{array}{c}\text { Growth } \\
\text { factor } \\
\text { production }\end{array}$ & $\begin{array}{l}\text { Direct } \\
\text { genotox- } \\
\text { icity }\end{array}$ & Apoptosis \\
\hline Asbestos & {$[21]$} & {$[4]$} & [23] & {$[16]$} & [8] & [14] fibroblasts & {$[15]$} & [3] \\
\hline Quartz & [9] & {$[17]$} & {$[18]$} & [20] & [6] & $\begin{array}{l}\text { [24] epithelial } \\
\text { cells }\end{array}$ & [35] & {$[12]$} \\
\hline $\mathrm{PM}_{10}$ & {$[19]$} & [13] & {$[22]$} & {$[65]$} & {$[5]$} & $\begin{array}{l}\text { [7] epithelial } \\
\text { cells }\end{array}$ & {$[\mathrm{II}]$} & {$[10]$} \\
\hline
\end{tabular}

may be more effective against PM than quartz or asbestos, since quartz or asbestos act via direct membrane/particle interactions as well as oxidative stress. The high particle numbers in the ultrafine fraction of $\mathrm{PM}_{10}$ may also lead to more interaction with the pulmonary epithelium in the case of PM, which may result in more epithelial injury or interstitialisation in the case of the latter, both of which could culminate in fibrosis.

\section{Bronchogenic carcinoma}

All 3 of the particle types addressed here have been associated with bronchogenic carcinoma (lung cancer). This is consistent with the airway epithelium as a primary site of deposition and therefore of highest dose. There could be differences in the mechanism of cancer, with the 3 particle types. Asbestos and quartz are essentially insoluble and so there are no readily identifiable lipophilic components that could enter the cells and form adducts with the epithelial cell DNA. Both asbestos [33] and quartz [34] can contain transition metals that could redox cycle and produce hydroxyl radicals which can form oxidative adducts like 8 hydroxy deoxyguanosine and activate signalling pathways which alter the balance between proliferation and apoptosis [35-37]. $\mathrm{PM}_{10}$, by contrast contains combustion-derived nanoparticles (soot) that contain PAHs along with other organics derived from fuel and its combustion. These have the potential to diffuse from the particle surface into cells and cause bulky DNA adducts.

\section{Cardiovascular effects}

This is seen only with $\mathrm{PM}_{10}$ and seems a special case of effects distal to the lungs. The most likely explanation is that $\mathrm{PM}_{10}$ exposure, unlike asbestos and quartz exposures, which occur in a workplace, is the only particle exposure that occurs in susceptible people with $\mathrm{cv}$ disease. In patients with severe cardiovascular disease, even a mild systemic oxidative stress or inflammatory effects arising in the lung can impact the cv system [38] and precipitate an acute coronary syndrome. This is supported by studies demonstrating clear adverse effects of acute diesel particle exposure on the endothelium [39] and on ischaemia in the ventricular myocardium [40]. In addition, pulmonary exposure to residual oil fly ash, a component of PM, has been shown to augment adhesion of PMN to systemic microvessels, induce ROS generation in these vessels, and decrease the ability of these microvessels to respond to dilators [41]. Additionally, the combustion-derived NP particles contained in $\mathrm{PM}_{10}$ may be able to enter the circulation, especially in compromised individuals, and directly adversely affect the endothelium/plaques [42].

\section{Pleural and peritoneal effects}

Pleural mesothelioma Mesothelioma is virtually unique to asbestos exposure, not being caused by any of the other particles. The target cell for mesothelioma is the mesothelium of the pleura or the peritoneum. It seems likely that asbestos fibres need to translocate to the pleural tissue to have this transforming effect and of course peripheral alveoli lie sub-pleurally and so any fibres that reach these peripheral alveoli and interstitialise, are close to the mesothelium. The pleura is 'reactive' to inflammation in the lungs [43] and the mesothelium undergoes proliferation when there is inflammation in the lung tissue [44]. Inflammation can be detected in the pleural space after lung exposure [45] to asbestos, and oxidative burst from the inflammatory leukocytes could be involved in producing mutation-forming oxidative adducts in the mesothelium but this has never been investigated.

Peritoneal mesothelioma This is an highly unusual tumour that, like its partner pleural mesothelioma, is only found with asbestos exposure. Since no other lung exposure, or lung disease, causes such a carcinogenic effect at a distal site, this argues for translocation of asbestos fibres to the peritoneal cavity. Other arguments, that oxidative stress or growth factor release from the lung reaching a sensitive site in the peritoneal mesothelium, are unlikely to be unique for asbestos alone. 
Pleural fibrosis Both asbestos and quartz cause pleural fibrosis but $\mathrm{PM}_{10}$ does not. Quartz is not, however, considered to be especially tropic for the pleura and so this may be a result of reactive changes due to high levels of growth factors produced locally in the peripheral parenchyma. $\mathrm{PM}_{10}$ does not cause pleural fibrosis and this is consistent with the relative paucity of impact that PM shows for the parenchyma, given the close association between the peripheral alveoli and the pleura.

Pleural plaques Only asbestos causes pleural plaques, thin plaques of acellular collagen on the parietal pleural surface. These are likely a reflection of translocation and the lymphatic, or other, delivery of fibres to the pleural space and the failure of longer fibres to be cleared via the stomata in the parietal pleura, the normal site for egress of lymph from the pleural space. Accumulation at these exit points of fibres on the pleura is likely to upset the normal serosal fibrinogenesis balance [46] allowing for a fibrinous exudates to form a scaffold for fibrosis. Alternatively, the presence of fibres on the mesothelium at the stomatal openings could set up a localised inflammatory response that is further 'irritated' by breath movements and the friction of the movement of the pleural surfaces over one another with maximal contact at the raised areas of the ribs. These events may combine to produce the characteristic highly localised fibrotic lesions of pleural plaque overlying the ribs.

\section{COPD}

COPD is a complex syndrome of two important pulmonary diseases-bronchitis and emphysema - that combine to produce airway narrowing. Although classically it is caused by cigarette smoking, the new definition includes gases and dusts as causative agents [47]. Airflow limitation is the characteristic manifestation of COPD, documented as a decline in $\mathrm{FEV}_{1}$. However there is another hallmark of the disease, namely, exacerbation. This is defined as a sudden worsening of the condition, often necessitating hospitalisation. $\mathrm{PM}_{10}$ has been implicated in causing one aspect of COPD - small airways fibrosis [30] and in causing exacerbations of COPD [48]. In one study, autopsy lungs from age-matched non-smoking females with no history of working in dusty occupations from a high $\mathrm{PM}_{10}$ pollution area Mexico City were compared with lungs from a similar population from low $\mathrm{PM}_{10}$ area - Vancouver [30]. Using morphometric techniques, considerable fibrosis was detected in the small airways of the Mexico City dwellers but very little of this type of pathology was seen in the Vancouver dwellers. This is evidence that $\mathrm{PM}_{10}$ causes one aspect of COPD, namely the fibrotic thickening of the small airways that contributes to airways obstruction. There are many time-series studies demonstrating that increases in PM10 cause exacerbations of COPD in the following hours [49]. There is no evidence that asbestos or quartz cause development of classical COPD (emphysema plus bronchitis with exacerbations) nor that either of these mineral particles causes exacerbation in existing COPD patients.

\section{Asthma}

Neither quartz, asbestos nor $\mathrm{PM}_{10}$ appear to 'cause' asthma in that there is no greater incidence of asthma amongst either workers or the general populations exposed to these particles. Increases in $\mathrm{PM}_{10}$ are, however, associated with increases in exacerbations of asthma in the hours following increased ambient PM exposure. The 'healthy worker effect' may explain this, in that no individual with airflow limitation would work in a dusty trade as they may anticipate or actually experience additional respiratory compromise from the dust exposure. In either case, they are unlikely to remain employed in such an industry and will seek alternative employment. This is not, of course, the case for $\mathrm{PM}_{10}$, where everyone, including asthmatics, experiences exposure with no choice in the matter.

\section{Extra-pulmonary effects}

Autoimmune disease Autoimmune disease is a common sequel of chronic inflammatory diseases $[50,51]$. It is seen in quartz and asbestos-exposed individuals [52] and may be a result of the severity of the inflammation seen with occupational exposure to quartz and asbestos. Lack of autoimmunity with $\mathrm{PM}_{10}$ exposure may reflect the relatively mild inflammation seen with $\mathrm{PM}_{10}$, supported by studies with concentrated ambient particles (CAPs) where only mild inflammation is seen even with CAPs at tens of times the ambient level [53].

Cardiovascular deaths and hospitalisations Exposure to $\mathrm{PM}_{10}$ in both chronic and short-term studies is associated with deaths and hospitalisations for cardiovascular causes $[40,54]$. The impact of particle inhalation on atherothrombosis, the principal cause of cardiovascular morbidity and mortality, is not well understood but there are a number of hypotheses. Pulmonary inflammation may be able to influence events in the atherosclerotic lesions in the vascular wall, which are also inflammation-driven [55]. Certainly acute effects such as endothelial dysfunction and ventricular ischaemia are pronounced in the short-term after exposure to diluted diesel exhaust in chamber studies $[39,56]$. Animal studies suggest that inflammation caused by pulmonary deposition of diesel particles can enhance the thrombogenicity of the blood [57]. Nurkiewicz et al. [41] have also reported that pulmonary exposure to residual oil fly ash causes PMN adherence and ROS production at systemic microvessels. In addition, nanoparticles in $\mathrm{PM}_{10}$ may be able to enter the circulation and directly affect the atherosclerotic plaque or the overlying endothelium [58]. 


\section{Similar effects of the different particles in vitro} It is clear from the above that the 3 different particle types cause a spectrum of adverse effects both in the lungs and at extra-pulmonary sites. This contrasts with the distinct similarities in the nature of the responses seen in in vitro studies with the same 3 particle types. This is shown in Table 2. All 3 particle types, when added to cells in culture, show abilities to cause oxidative stress, activation of redox-sensitive transcription factors, cytokine and chemokine production, growth factor release, and direct genotoxicity.

Oxidative stress is a strong over-arching theme in the cellular effects of particles. In general, the responses to particles can be understood as responses to oxidative stress. Most pathogenic particles appear to cause oxidative stress in target cells. The ubiquitousness of this effect is striking and may reflect some fundamental response of cells to foreign surfaces inside the cell as well as the obvious redox-cycling of some particle components like organics [59] and transition metals [60]. Oxidative stress is a signalling system in cells that leads to gene expression [61]. Increasing levels of oxidative stress inside cells caused by particles may result in graded response from anti-oxidant defence induction via NF- $\mathrm{KB}$ and $\mathrm{AP}-1$, through proinflammatory signalling via the same transcription factors to induction of apoptosis [1]. Therefore it is something of a self-fulfilling prophecy that adding particle to cells will cause oxidative stress if the dose is high enough, and that if there is oxidative stress there will be NF- $\mathrm{B}$ and AP-1 activation. The activation of the transcription factors is tightly related to redox balance in the cell. There may be exceptions, however, and in our hands quartz and raw carbon nanotubes (metal contaminated) cause the same degree of glutathione depletion but only quartz causes NF- $\kappa \mathrm{B}$ activation. Therefore particle-derived oxidative stress alone may not be sufficient but may often be accompanied by one or more other signals to the cells from the particles for transcription. It has been proposed that the more pathogenic the particle, the more it causes oxidative stress [1]. However, this relationship does not hold for purified (low metal) single-walled carbon nanotubes. Although raw single-walled carbon nanotubes have been shown to be toxic to bronchial epithelial cells in vitro, ROS generation and oxidant damage appear dependent on the presence of contaminating iron [62]. Indeed, in vitro exposure of macrophages to purified single-walled carbon nanotubes failed to induce ROS production or stimulate production of inflammatory cytokines [27].

Release of chemokines, cytokines and growth factors can be grouped together as they are all secretions from cells, normally leukocytes, that induce inflammation or mesenchymal cell activation or proliferation. Once again all of the particles considered here when added to one target cell or another stimulate the gene expression and release of these mediators. Macrophage-derived cytokines, such as TNF $\alpha$, act on epithelial cells to enhance their chemokine response to particles $[63,64]$. Many cytokines and chem-

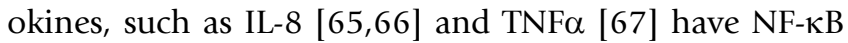
motifs in their promoter and are oxidative stress-responsive and so their activation is to be anticipated, if oxidative stress is present.

Genotoxicity and apoptosis are linked together because of the relationship between genotoxicity and the induction of apoptosis [68]; again there is a common role for oxidative stress in both processes. However, purified singlewalled carbon nanotubes appear to be an exception to this rule, since inhalation exposure in mice caused k-ras gene mutation without persistent oxidant stress [28].

\section{Conclusion and relevance for predictive toxicology of nanoparticles}

Taken together, these in vitro data tell us that oxidative stress is a central tenet of the current hypothesis on the action of particles at the cellular level. This is in keeping with understood actions of a large number of chemicals, such as metals, organics, etc., that also act by causing oxidative stress in various target tissues and organs [69-75] (Figure 1). This suggests that the information that is garnered from a study that demonstrates that a particle can cause oxidative stress in vitro may be of highly questionable value. The real question is whether different particles have different abilities to deliver oxidative stress and possibly the nature of the oxidative stress or its site of delivery both inside the cell and in target tissues distant to the airspace surface on which the particle deposits. The latter implies a need for toxicokinetics to understand plausible dose in any target tissue. Such toxicokinetics as has been carried out on particles suggests, for example, that particle size is related to translocation, and that larger particles do not on the whole translocate to any appreciable degree, except for asbestos. This seems evident from Figure 1, where asbestos seems to be able to translocate most efficiently and has the smallest or at least thinnest particles.

At the moment the particle toxicology world is dominated by the issue of nanotoxicology and the effects of nanoparticles. The experience with combustion-derived nanoparticles and $\mathrm{PM}_{10}$ and some studies with manufactured nanoparticles suggest that there could be risk from the development and use of manufactured nanoparticles. There are many new particle types that await testing, but there is no great appetite for animal testing. Thus, there is a perceived need for in vitro testing that can predict the hazard. It might be tempting to carry out in vitro toxicology alone, and it might not be surprising to find that some of these particles cause oxidative stress and NF- $\kappa \mathrm{B}$ activation etc. [1]. However, purified single-walled carbon nan- 

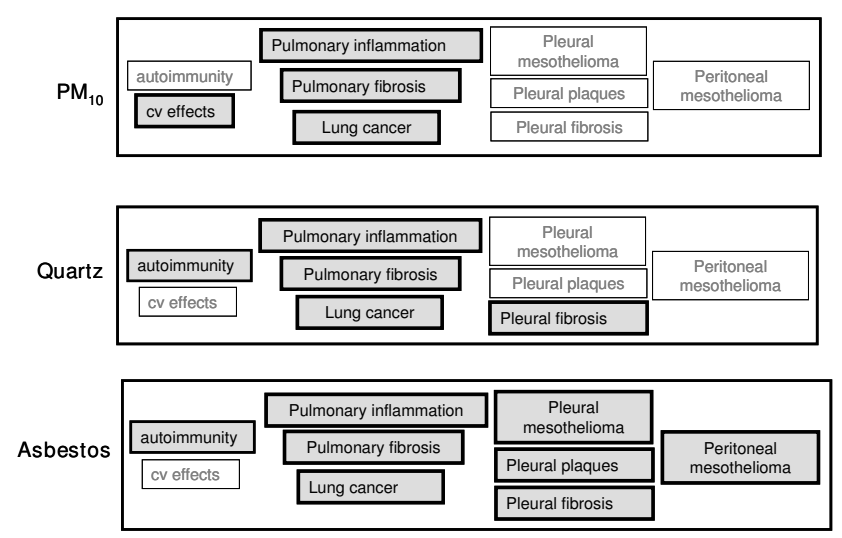

Figure I

How different particle types affect different pathological compartments; where there is an impact the typeface is bold and the box outline is thicker.

otubes appear to be an exception to this general rule [27]. In this case, direct action on lung fibroblasts (increase proliferation, augmentation of collagen production, and induction of cytokine message) rather than oxidant stress may explain the in vivo response (interstitial fibrosis) to single-walled carbon nanotubes [76,77]. The content of the present paper, however, suggests that great care should be taken in interpreting in vitro data. A particle that causes oxidative stress to cells in culture could, in theory, behave like quartz, asbestos or $\mathrm{PM}_{10}$, and it would not be evident which of these it would behave like, from the in vitro data.

Short of waiting for the diseases themselves to develop, what can we do to assist in bridging the gap between in vitro and disease prediction, Dosimetry data is one way forward but this is notoriously difficult and there is no mass balance toxicokinetic data available for any particle. It seems unlikely that PBPK modelling can adequately predict nanoparticle dosimetry, although there are ongoing efforts. Toxicokinetics is difficult and expensive but offers the only way forward in order to put in vitro studies on a relevant and plausible footing with regard to dose to use, target cells to study, and ultimately, the usefulness in hazard identification.

None of the above is meant to say that in vitro toxicology isn't valuable for understanding mechanisms. It is absolutely vital for this purpose and has formed the backbone of the authors' research. However, in vitro research cannot replace some aspects of animal testing, and there is need for investment in good nanotoxicology research across all aspects of the discipline to gain the advances in understanding that are needed.

In addition to providing toxicokinetics and dosimetric data, in vivo testing of nanoparticles also remains impor- tant because of the possibility of picking up a novel pathology or target tissue. In vivo testing also sidesteps the difficulty in linking "generic" cellular responses to different pathologies but is also needed because no, or only poor, in vitro alternatives currently exist for many "systemic" responses such as cardiovascular responses, immune responses and syndromes such as COPD. We need to continue to invest in in vivo testing because many diseases linked to nanoparticles are systemic in nature. In addition the distribution of nanoparticles in different organs and tissue is poorly studied. At the same time, toxicologists need both in vivo and in vitro models to study the pathogenesis of these diseases and the behaviour of nanoparticles at all levels, organismal to sub-cellular. Only limited progress has been made in developing in vitro models to study the distribution and translocation of nanoparticles across the different barriers. More effort is urgently needed develop more specific in vitro models that will enable us to understand systemic effects of nanomaterials.

\section{Competing interests}

The authors declare that they have no competing interests.

\section{Authors' contributions}

All of the authors contributed, in equal measure, their experience in the toxicology of fibres and particles in the conception and writing of this review. All authors read and approved the final manuscript.

\section{Disclaimer}

The findings and conclusions in this report are those of the authors and do not necessarily represent the views of the National Institute for Occupational Safety and Health.

\section{Acknowledgements}

D would like to acknowledge the financial support of the Colt Foundation

\section{References}

I. Nel A, Xia T, Madler L, Li N: Toxic potential of materials at the nanolevel. Science 2006, 3 I I:622-627.

2. Oberdorster G, Maynard A, Donaldson K, Castranova V, Fitzpatrick J, Ausman K, Carter J, Karn B, Kreyling W, Lai D, et al.: Principles for characterizing the potential human health effects from exposure to nanomaterials: elements of a screening strategy. Part Fibre Toxicol 2005, 2:8.

3. BeruBe KA, Quinlan TR, Fung H, Magae J, Vacek P, Taatjes DJ, Mossman BT: Apoptosis is observed in mesothelial cells after exposure to crocidolite asbestos. Am J Respir Cell Mol Biol 1996, I5:|4|-|47.

4. Brown DM, Beswick PH, Donaldson K: Induction of nuclear translocation of NF-kappaB in epithelial cells by respirable mineral fibres. J Pathol 1999, 189:258-264.

5. Brown DM, Hutchison L, Donaldson K, Stone V: The effects of PMIO particles and oxidative stress on macrophages and lung epithelial cells: modulating effects of calcium-signaling antagonists. Am J Physiol Lung Cell Mol Physiol 2007, 292:L I 444- I 45 I.

6. Bruch J, Rehn S, Rehn B, Borm PJ, Fubini B: Variation of biological responses to different respirable quartz flours determined by a vector model. Int J Hyg Environ Health 2004, 207:203-216.

7. Dagher Z, Garcon G, Gosset P, Ledoux F, Surpateanu G, Courcot D, Aboukais A, Puskaric E, Shirali P: Pro-inflammatory effects of 
Dunkerque city air pollution particulate matter $\mathbf{2 . 5}$ in human epithelial lung cells (LI32) in culture. J Appl Toxicol 2005, 25:166-175

8. Dogra S, Donaldson K: Effect of long and short fibre amosite asbestos on in vitro TNF production by rat alveolar macrophages: the modifying effect of lipopolysaccharide. Ind Health 1995, 33:|3|-|4|.

9. Donaldson K, Borm PJ: The quartz hazard: a variable entity. Ann Occup Hyg 1998, 42:287-294.

10. Gilmour PS, Morrison ER, Vickers MA, Ford I, Ludlam CA, Greaves $M$, Donaldson K, MacNee W: The procoagulant potential of environmental particles (PMI0). Occup Environ Med 2005, 62:164-17|.

11. Hsiao WL, Mo ZY, Fang M, Shi XM, Wang F: Cytotoxicity of $\operatorname{PM}(2.5)$ and $\operatorname{PM}(2.5-10)$ ambient air pollutants assessed by the MTT and the Comet assays. Mutat Res 2000, 47 I:45-55.

12. lyer R, Hamilton RF, Li L, Holian A: Silica-induced apoptosis mediated via scavenger receptor in human alveolar macrophages. Toxicol Appl Pharmacol 1996, 141:84-92.

13. Jimenez LA, Thompson J, Brown DA, Rahman I, Antonicelli F, Duffin R, Drost EM, Hay RT, Donaldson K, MacNee W: Activation of NFkappaB by PM(10) occurs via an iron-mediated mechanism in the absence of IkappaB degradation. Toxicol Appl Pharmacol 2000, 166:101-110.

14. Lasky JA, Bonner JC, Tonthat B, Brody AR: Chrysotile asbestos induces PDGF-A chain-dependent proliferation in human and rat lung fibroblasts in vitro. Chest 1996, 109:26S-28S.

15. Ollikainen T, Linnainmaa K, Kinnula VL: DNA single strand breaks induced by asbestos fibers in human pleural mesothelial cells in vitro. Environ Mol Mutagen 1999, 33:153-160.

16. Rosenthal G], Germolec DR, Blazka ME, Corsini E, Simeonova P, Pollock P, Kong LY, Kwon J, Luster MI: Asbestos stimulates IL-8 production from human lung epithelial cells. J Immunol 1994 I 53:3237-3244.

17. Schins RP, McAlinden A, MacNee W, Jimenez LA, Ross JA, Guy K, Faux SP, Donaldson K: Persistent depletion of I kappa B alpha and interleukin-8 expression in human pulmonary epithelial cells exposed to quartz particles. Toxicol Appl Pharmacol 2000, 167:107-117.

18. Shukla A, Timblin CR, Hubbard AK, Bravman J, Mossman BT: Silicainduced activation of c-Jun-NH2-terminal amino kinases, protracted expression of the activator protein-I proto-oncogene, fra-I, and S-phase alterations are mediated via oxidative stress. Cancer Res 200I, 61:179I-1795.

19. Squadrito GL, Cueto R, Dellinger B, Pryor WA: Quinoid redox cycling as a mechanism for sustained free radical generation by inhaled airborne particulate matter. Free Radic Biol Med 2001, 31:1132-1138.

20. Stringer B, Imrich A, Kobzik L: Lung epithelial cell (A549) interaction with unopsonized environmental particulates: quantitation of particle-specific binding and IL-8 production. Exp Lung Res 1996, 22:495-508.

21. Suzuki K, Hei TK: Induction of heme oxygenase in mammalian cells by mineral fibers: distinctive effect of reactive oxygen species. Carcinogenesis 1996, 17:661-667.

22. Timblin C, BeruBe K, Churg A, Driscoll K, Gordon T, Hemenway D, Walsh E, Cummins AB, Vacek P, Mossman B: Ambient particulate matter causes activation of the c-jun kinase/stress-activated protein kinase cascade and DNA synthesis in lung epithelial cells. Cancer Res 1998, 58:4543-4547.

23. Timblin CR, Guthrie GD, Janssen YW, Walsh ES, Vacek P, Mossman BT: Patterns of c-fos and c-jun proto-oncogene expression, apoptosis, and proliferation in rat pleural mesothelial cells exposed to erionite or asbestos fibers. Toxicol Appl Pharmacol 1998, I5 I:88-97.

24. Williams $A O$, Knapton $A D$, Ifon ET, Saffiotti U: Transforming growth factor beta expression and transformation of rat lung epithelial cells by crystalline silica (quartz). Int J Cancer 1996, 65:639-649.

25. IARC: IARC Monographs on the evaluation of Carcinogenic Risks to Humans: In Man Made Vitreous Fibres Lyon: IARC; 2002.

26. Wallace WE, Keane MJ, Mike PS, Hill CA, Vallyathan V, Regad ED: Contrasting respirable quartz and kaolin retention of lecithin surfactant and expression of membranolytic activity following phospholipase A2 digestion. J Toxicol Environ Health 1992 , 37:391-409.
27. Shvedova AA, Kisin ER, Mercer R, Murray AR, Johnson VJ, Potapovich Al, Tyurina YY, Gorelik O, Arepalli S, Schwegler-Berry D, et al.: Unusual inflammatory and fibrogenic pulmonary responses to single-walled carbon nanotubes in mice. Am J Physiol Lung Cell Mol Physiol 2005, 289:L698-708.

28. Shvedova AA, Kisin ER, Murray AR, Johnson VJ, Gorelik O, Arepalli S, Hubbs AF, Mercer RR, Keohavong P, Sussman N, et al.: Inhalation Versus Aspiration of Single Walled Carbon Nanotubes in C57bl/6 Mice: Inflammation, Fibrosis, Oxidative Stress and Mutagenesis. Am J Physiol Lung Cell Mol Physiol 2008.

29. Craighead JE, Abraham JL, Churg A, Green FH, Kleinerman J, Pratt PC, Seemayer TA, Vallyathan V, Weill H: The pathology of asbestos-associated diseases of the lungs and pleural cavities: diagnostic criteria and proposed grading schema. Report of the Pneumoconiosis Committee of the College of American Pathologists and the National Institute for Occupational Safety and Health. Arch Pathol Lab Med 1982, 106:544-596.

30. Churg A, Brauer M, del Carmen Avila-Casado M, Fortoul TI, Wright $\mathrm{JL}$ : Chronic exposure to high levels of particulate air pollution and small airway remodeling. Environ Health Perspect 2003, III:7|4-7|8.

31. Weiss W: Smoking and pulmonary fibrosis. J Occup Med 1988, 30:33-39.

32. Invernizzi G, Boffi R, Ruprecht AA, Barnes PJ, Kharitonov SA, Paredi $P$ : Real-time measurement of particulate matter deposition in the lung. Biomarkers 2006, II:221-232.

33. Lund LG, Aust AE: Iron mobilization from crocidolite asbestos greatly enhances crocidolite-dependent formation of DNA single-strand breaks in phi XI 74 RFI DNA. Carcinogenesis 1992, 13:637-642.

34. Castranova V, Vallyathan V, Ramsey DM, McLaurin JL, Pack D, Leonard S, Barger MW, Ma JY, Dalal NS, Teass A: Augmentation of pulmonary reactions to quartz inhalation by trace amounts of iron-containing particles. Environ Health Perspect 1997. 105(Suppl 5):1319-1324.

35. Schins RP, Knaapen AM, Cakmak GD, Shi T, Weishaupt C, Borm PJ: Oxidant-induced DNA damage by quartz in alveolar epithelial cells. Mutat Res 2002, 51 7:77-86.

36. Shi X, Castranova V, Halliwell B, Vallyathan V: Reactive oxygen species and silica-induced carcinogenesis. J Toxicol Environ Health B Crit Rev 1998, 1:181-197.

37. Ding M, Dong Z, Chen F, Pack D, Ma WY, Ye J, Shi X, Castranova V, Vallyathan $\mathrm{V}$ : Asbestos induces activator protein-I transactivation in transgenic mice. Cancer Res 1999, 59:1884-1889.

38. Clayton TC, Thompson M, Meade TW: Recent respiratory infection and risk of cardiovascular disease: case-control study through a general practice database. Eur Heart J 2008, 29:96-103.

39. Mills NL, Tornqvist H, Robinson SD, Gonzalez M, Darnley K, MacNee W, Boon NA, Donaldson K, Blomberg A, Sandstrom T, Newby DE: Diesel exhaust inhalation causes vascular dysfunction and impaired endogenous fibrinolysis. Circulation 2005, I I 2:3930-3936.

40. Mills N, Tornqvist H, Gonzalez M, Robinson SD, MacNee W, Blomberg A, Donaldson K: Adverse cardiovascular effects of air pollution in patients with coronary heart disease. J Am Coll Cardiol 2007 in press.

41. Nurkiewicz TR, Porter DW, Barger M, Millecchia L, Rao KM, Marvar PJ, Hubbs AF, Castranova V, Boegehold MA: Systemic microvascular dysfunction and inflammation after pulmonary particulate matter exposure. Environ Health Perspect 2006, I | 4:4 | 2-4 I9.

42. Donaldson K, Tran L, Jimenez LA, Duffin R, Newby DE, Mills N, MacNee W, Stone V: Combustion-derived nanoparticles: a review of their toxicology following inhalation exposure. Part Fibre Toxicol 2005, 2: 10 .

43. Li XY, Brown GM, Lamb D, Donaldson K: Reactive pleural inflammation caused by intratracheal instillation of killed microbes. Eur Respir J 1993, 6:27-34.

44. Adamson IY, Bakowska J, Bowden DH: Mesothelial cell proliferation: a nonspecific response to lung injury associated with fibrosis. Am J Respir Cell Mol Biol 1994, 10:253-258.

45. Li XY, Lamb D, Donaldson K: Production of interleukin I by rat pleural leucocytes in culture after intratracheal instillation of crocidolite asbestos. Br J Ind Med 1993, 50:90-94.

46. Li XY, Brown GM, Lamb D, Donaldson K: Increased production of plasminogen activator inhibitor in vitro by pleural leuko- 
cytes from rats intratracheally instilled with crocidolite asbestos. Environ Res 1991, 55:135-144.

47. Churg A, Green FH: Pathology of Occupational Lung Disease 2nd edition. Baltimore: Williams and Wilkins; 1999.

48. Wordley J, Walters S, Ayres JG: Short term variations in hospital admissions and mortality and particulate air pollution. Occup Environ Med 1997, 54: I08-II6.

49. Sint T, Donohue JF, Ghio AJ: Ambient air pollution particles and the acute exacerbation of chronic obstructive pulmonary disease. Inhal Toxicol 2008, 20:25-29.

50. Paunovic V, Carroll HP, Vandenbroeck K, Gadina M: Signalling, inflammation and arthritis: crossed signals: the role of interleukin (IL)- 1 2, - 17, -23 and -27 in autoimmunity. Rheumatology (Oxford) 2008, 47:77।-776.

5I. Smedby KE, Baecklund E, Askling J: Malignant lymphomas in autoimmunity and inflammation: a review of risks, risk factors, and lymphoma characteristics. Cancer Epidemiol Biomarkers Prev 2006, I 5:2069-2077.

52. Otsuki T, Maeda M, Murakami S, Hayashi H, Miura Y, Kusaka M, Nakano T, Fukuoka K, Kishimoto T, Hyodoh F, et al:: Immunological effects of silica and asbestos. Cell Mol Immunol 2007, 4:26I-268.

53. Ghio AJ, Kim C, Devlin RB: Concentrated ambient air particles induce mild pulmonary inflammation in healthy human volunteers. Am J Respir Crit Care Med 2000, 162:98I-988.

54. Mills NL, Tornqvist H, Robinson SD, Gonzalez MC, Soderberg S, Sandstrom T, Blomberg A, Newby DE, Donaldson K: Air pollution and atherothrombosis. Inhal Toxicol 2007, I9(Suppl I):8I-89.

55. Libby P, Ridker PM, Maseri A: Inflammation and atherosclerosis. Circulation 2002, 105: I|35-1/43.

56. Mills NL, Tornqvist H, Gonzalez MC, Vink E, Robinson SD, Soderberg S, Boon NA, Donaldson K, Sandstrom T, Blomberg A, Newby DE: Ischemic and thrombotic effects of dilute diesel-exhaust inhalation in men with coronary heart disease. N Engl J Med 2007, 357:1075-1082.

57. Nemmar A, Hoet PH, Dinsdale D, Vermylen J, Hoylaerts MF, Nemery $B$ : Diesel exhaust particles in lung acutely enhance experimental peripheral thrombosis. Circulation 2003, 107:1202-1208.

58. Kreyling WG, Moller W, Semmler-Behnke M, Oberdorster G: Particle dosimetry: Deposition and clearance from the respiratory tract and translocation to extra-pulmonary sites. In Particle Toxicology Volume Chapter 3. Edited by: Donaldson K, Boem P. Boca Raton, USA. CRC Press; 2007:47-74.

59. Dellinger B, Pryor WA, Cueto R, Squadrito GL, Hegde V, Deutsch WA: Role of free radicals in the toxicity of airborne fine particulate matter. Chem Res Toxicol 200 I, I 4: I37|-1377.

60. Aust AE, Ball JC, Hu AA, Lighty JS, Smith KR, Straccia AM, Veranth JM, Young WC: Particle characteristics responsible for effects on human lung epithelial cells. Res Rep Health Eff Inst 2002: I-65. discussion 67-76

61. Mossman BT, Lounsbury KM, Reddy SP: Oxidants and signaling by mitogen-activated protein kinases in lung epithelium. Am J Respir Cell Mol Biol 2006, 34:666-669.

62. Shvedova AA, Kisin ER, Murray AR, Schwegler-Berry D, Gandelsman VZ, Baron P, Maynard A, Gunter MR, Castranova V: Exposure of human bronchial epithelial cells to carbon nanotubes caused oxidative stress and cytotoxicity. Proc Soc Free Rad Res Meeting, European Section, Jan 26-29, loannina, Greece 2003:91-103.

63. Driscoll KE, Hassenbein DG, Carter JM, Kunkel SL, Quinlan TR, Mossman BT: TNF alpha and increased chemokine expression in rat lung after particle exposure. Toxicol Lett 1995, 8283:483-489.

64. Jimenez LA, Drost EM, Gilmour PS, Rahman I, Antonicelli F, Ritchie $\mathrm{H}$, MacNee W, Donaldson K: PM(I0)-exposed macrophages stimulate a proinflammatory response in lung epithelial cells via TNF-alpha. Am J Physiol Lung Cell Mol Physiol 2002, 282:L237-248.

65. Gilmour PS, Rahman I, Donaldson K, MacNee W: Histone acetylation regulates epithelial IL-8 release mediated by oxidative stress from environmental particles. Am J Physiol Lung Cell Mol Physiol 2003, 284:L533-540.

66. Driscoll KE: TNFalpha and MIP-2: role in particle-induced inflammation and regulation by oxidative stress. Toxicol Lett 2000, II 2-I I3:177-183.

67. Janssen-Heininger YM, Macara I, Mossman BT: Cooperativity between oxidants and tumor necrosis factor in the activa- tion of nuclear factor (NF)-kappaB: requirement of Ras/ mitogen-activated protein kinases in the activation of NFkappaB by oxidants. Am J Respir Cell Mol Biol 1999, 20:942-952.

68. Kastan MB, Canman CE, Leonard CJ: P53, cell cycle control and apoptosis: implications for cancer. Cancer Metastasis Rev 1995, 14:3-15.

69. Kappus $\mathrm{H}$ : Oxidative stress in chemical toxicity. Arch Toxicol 1987, 60: 144-149.

70. Wells PG, Kim PM, Laposa RR, Nicol CJ, Parman T, Winn LM: Oxidative damage in chemical teratogenesis. Mutat Res 1997, 396:65-78.

7I. Klaunig JE, Xu Y, Isenberg JS, Bachowski S, Kolaja KL, Jiang J, Stevenson DE, Walborg EF Jr: The role of oxidative stress in chemical carcinogenesis. Environ Health Perspect 1998, I06(Suppl I):289-295.

72. Golding BT, Watson WP: Possible mechanisms of carcinogenesis after exposure to benzene. IARC Sci Publ 1999:75-88.

73. Shi $\mathrm{H}$, Hudson LG, Liu KJ: Oxidative stress and apoptosis in metal ion-induced carcinogenesis. Free Radic Biol Med 2004, 37:582-593.

74. Gonzalez F): Role of cytochromes P450 in chemical toxicity and oxidative stress: studies with CYP2EI. Mutat Res 2005, 569: $101-110$.

75. Magder S: Reactive oxygen species: toxic molecules or spark of life? Crit Care 2006, 10:208.

76. Wang L, Castranova V, Rojanasakul Y, Lu Y, Scabilloni J, Mercer RR: Direct fibrogenic effects of dispersed single walled carbon nanotubes on human lung fibroblasts. The Toxicol 2008, 102:AI499.

77. Kagan VE, Rao KM, Kisin ER, Young S-H, Meighan T, Murray AR, Tyurina YY, Castranova V, Shvedova AA: Pulmonary effects of single walled carbon nanotubes: inflammatory, oxidative stress/signalling, and recognition by macrophages. In NATO Series, Nanotechnology - Toxicological Issues and Environmental Safety Springer; 2007:65-67.
Publish with BioMed Central and every scientist can read your work free of charge

"BioMed Central will be the most significant development for disseminating the results of biomedical research in our lifetime. "

Sir Paul Nurse, Cancer Research UK

Your research papers will be:

- available free of charge to the entire biomedical community

- peer reviewed and published immediately upon acceptance

- cited in PubMed and archived on PubMed Central

- yours - you keep the copyright
BioMedcentral 